\title{
65. REVIEW OF MAGNETIC PROPERTIES OF BASALTS AND SEDIMENTS, LEG 34
}

\author{
J.M. Ade-Hall, Department of Geology, Dalhousie University, Halifax, Nova Scotia, Canada \\ and \\ Harlan Paul Johnson, CIRES, P.S.R.B. No. 1, University of Colorado, Boulder, Colorado
}

\section{INTRODUCTION}

One of the two main aims of Leg 34 of the Deep Sea Drilling Project was to make the first planned attempt at deep penetration of oceanic volcanic basement, the layer 2 of oceanic refraction seismology. In order to take full advantage of the anticipated recovery of considerable sections of strongly magnetized volcanics, a program of magnetic and related opaque petrographic studies, involving eight groups, was planned. In this way we ensured that all the relevant magnetic tests would be made on the material with, in most instances, duplication of each test at several laboratories. This program has worked very effectively, with all groups meeting their respective commitments in producing a chapter for this Initial Report volume. Although drilling conditions at the Leg 34 sites proved to be more difficult than expected, with only 105 meters of net basement penetration and 15 meters of recovery, nearly 200 samples were taken on Glomar Challenger for magnetic tests in the ship-and shore-based laboratories. This chapter describes the collected magnetic measurements for this large set of samples. In summarizing the results of the eight groups involved we have tried to act as reporters rather than reviewers, but where there are differences in results for obviously similar samples or differences in interpretation of similar results, we have given what we consider the best supported conclusion. The authors of the reports synthesized here have had the opportunity to comment on our conclusions.

\section{GEOLOGICAL SETTING AND MAIN RESULTS FROM THE LEG 34 SITES}

Basement penetration recovered basalts at the three Nazca plate Sites-319, 320, and 321-with two closely adjacent holes at Site 319 (Holes 319 and 319A) both yielding basement material. Four holes were drilled at Site 320 but only one (320B) penetrated basement. At Site 321 the single hole penetrated basement. All the sites were located within the Nazca plate in oceanic crust generated at the now extinct Galapagos Rise. Westward spreading rise migration of about $1000 \mathrm{~km}$ from the site of the Galapagos Rise to form the present East Pacific Rise took place at close to 6 million years ago (Herron, 1972; Anderson and Sclater, 1972; Ade-Hall, Underway Surveys, this volume). Site 319 was drilled in the Bauer Deep, the depression between the Galapagos and East Pacific rises, about $800 \mathrm{~km}$ west of the crest of the Galapagos Rise. Sites 320 and 321 were drilled on the lower east flank of the Galapagos Rise crest to the north and south, respectively, of the Mendaña Fracture Zone and at a few hundred kilometers from the Peru-Chile
Trench. Table 1 lists the features of the geology of each site relevant to the magnetic studies.

\section{WORK PLAN}

Table 2 tabulates the division of the various magnetic and opaque petrographic studies between the eight laboratories involved.

\section{THE MAGNETIZATION OF THE OCEAN CRUST AT THE DRILL SITES}

In this section we summarize the collected results concerned with the total magnetization of the ocean crust at the three drilling sites. This magnetization comprises the contribution of the sediments and of the uppermost few tens of meters of volcanic basement. A full description of the magnetization of each layer should give the in situ remanent, induced, and viscous contributions for sediments and basalts, together with the stable NRM directions obtained after remanence cleaning. With this information we should be able to describe the present net magnetization of the uppermost ocean crust and provide information relevant to one or more of the following: plate motion since formation, magnetic field conditions at the time of formation, and the local volcanic and tectonic history.

Paper 8 describes the remanent magnetization of the lower sediments at each site. The light brown nannooozes provide the best material for measurement, being generally stable and relatively strongly magnetized. Remanence intensities, which were easily measurable on Glomar Challenger using a Schonstedt SSM la spinner magnetometer, average $2.8 \pm 0.4 \times 10^{-6} \mathrm{emu} \mathrm{cm}^{-3}$ at Site 319; $1.7 \pm 0.3 \times 10^{-6} \mathrm{emu} \mathrm{cm}^{-3}$ at Site 320; and 6.4 $\pm 1.6 \times 10^{-6} \mathrm{emu} \mathrm{cm}{ }^{-3}$ at Site 321 (ranges are standard deviations of the mean value). Susceptibilities were unmeasurable with a Soil Test MS-3 bridge and are probably well less than $2 \times 10^{-5} \mathrm{emu} \mathrm{cm}^{-3} \mathrm{oe}^{-1}$, the minimum detectable level. No measurements of the sediment VRM acquisition behavior have been made, however, this is unlikely to exceed significantly the NRM intensities. Thus, while the sediment NRMs are readily measurable, the contribution of the 100 to 200 meter thick sediment sequence to the anomaly field associated with the oceanic crust at the sites will be negligible, since the underlying basalts are more strongly magnetized by two to three orders of magnitude. Satisfactory cleaned NRM directions for the sediments were obtained for 32 of the 36 samples. Without absolute declination information, proper averaging of the shallow lying inclinations is difficult, as a distinction between $\mathrm{N}$ and $\mathrm{R}$ directions generally cannot be made. By making extreme assumptions two limiting average in- 
TABLE 1

Geologic Features of Leg 34 Sites

\begin{tabular}{|c|c|c|c|c|}
\hline $\begin{array}{l}\text { Site, Location, } \\
\text { Water Depth } \\
\text { (m) }\end{array}$ & $\begin{array}{l}\text { Sediment } \\
\text { Thickness }(\mathrm{m}) \\
\text { and Type }\end{array}$ & $\begin{array}{c}\text { Basement } \\
\text { Penetration and } \\
\text { Lithology }\end{array}$ & $\begin{array}{c}\text { Estimated } \\
\text { Age of Oldest } \\
\text { Sediment (m.y.) }\end{array}$ & $\begin{array}{l}\text { Magnetic } \\
\text { Anomaly Age } \\
\text { at Site }\end{array}$ \\
\hline $\begin{array}{c}319 \\
13^{\circ} 01.04^{\prime} \mathrm{S} \\
101^{\circ} 31.46^{\prime} \mathrm{W} \\
4296\end{array}$ & $\begin{array}{l}110 / 98(319 / 319 \mathrm{~A}) \\
\text { Metalliferous nanno } \\
\text { clay and ooze }\end{array}$ & $\begin{array}{l}59.5 \mathrm{~m} \text {; probable } \\
\text { pillow lava } \\
\text { sequences above } \\
\text { and below } \\
\text { massive units }\end{array}$ & $14-15$ & Indeterminate \\
\hline $\begin{array}{c}320 \\
9^{\circ} 00.40^{\prime} \mathrm{S} \\
83^{\circ} 31.80^{\prime} \mathrm{W} \\
4487\end{array}$ & $\begin{array}{l}164.5 \text { Iron-rich } \\
\text { nanno-foram ooze }\end{array}$ & $\begin{array}{l}28.5 \mathrm{~m} ; \text { probable } \\
\text { pillow lava } \\
\text { sequence }\end{array}$ & $26-30$ & Indeterminate \\
\hline $\begin{array}{c}321, \\
12^{\circ} 01.20^{\prime} \mathrm{S} \\
81^{\circ} 54.24^{\prime} \mathrm{W} \\
4827\end{array}$ & $\begin{array}{l}124 \text { Grey then } \\
\text { brown clay over } \\
\text { ferruginous } \\
\text { nanno ooze }\end{array}$ & $\begin{array}{l}10.5 \mathrm{~m} \text {; thin } \\
\text { cap of fine- } \\
\text { grained basalt } \\
\text { over massive } \\
\text { basalt }\end{array}$ & $39-40$ & $\begin{array}{l}39.5 \text { m.y. } \\
\text { (just younger } \\
\text { than anomaly } \\
16 \text { ) }\end{array}$ \\
\hline
\end{tabular}

TABLE 2

Division of Various Magnetic and Opaque Petrographic Studies

\begin{tabular}{|c|c|c|c|}
\hline Laboratory & Investigators & Range of Tests Carried Out & $\begin{array}{l}\text { Reference to } \\
\text { Paper in this } \\
\text { Chapter }\end{array}$ \\
\hline $\begin{array}{l}\text { USGS, Menlo Park, } \\
\text { California }\end{array}$ & Grommé and Mankinen & $\begin{array}{l}\text { NRM of basalts with AF } \\
\text { cleaning, initial } \\
\text { susceptibility; saturation } \\
\text { magnetization with tem- } \\
\text { perature }\left(J_{s-t}\right) \text {; X-ray of } \\
\text { magnetic separates }\end{array}$ & 1 \\
\hline $\begin{array}{l}\text { Memorial } \\
\text { University of } \\
\text { Newfoundland }\end{array}$ & Deutsch and Patzold & $\begin{array}{l}\text { NRM of basalts with AF } \\
\text { and continuous and step- } \\
\text { wise thermal cleaning, } \\
k-T, \text { low and high field } \\
\text { hysteresis loops at } \\
\text { ambient and liquid } \\
\text { nitrogen temperatures }\end{array}$ & 2 \\
\hline $\begin{array}{l}\text { University of } \\
\text { Miami }\end{array}$ & $\begin{array}{l}\text { Tarasiewicz, Tarasiewicz, } \\
\text { and Harrison }\end{array}$ & $\begin{array}{l}\text { NRM of basalts with AF } \\
\text { cleaning, VRM of basalts }\end{array}$ & 3 \\
\hline $\begin{array}{l}\text { Lamont Doherty } \\
\text { Geological } \\
\text { Observatory }\end{array}$ & Lowrie and Kent & $\begin{array}{l}\text { NRM of basalts with AF } \\
\text { cleaning, VRM of basalts }\end{array}$ & 4 \\
\hline $\begin{array}{l}\text { Woods Hole } \\
\text { Oceanographic } \\
\text { Institution }\end{array}$ & Denham and Guertler & $\begin{array}{l}\text { NRM of basalts with AF } \\
\text { cleaning, VRM of basalts }\end{array}$ & 5 \\
\hline $\begin{array}{l}\text { University of } \\
\text { Rhode Island }\end{array}$ & Ellwood and Watkins & Susceptibility anisotropy & 6 \\
\hline $\begin{array}{l}\text { Glomar Challenger/ } \\
\text { Dalhousie } \\
\text { University }\end{array}$ & Ade-Hall and Johnson & $\begin{array}{l}\text { NRM of basalts with AF } \\
\text { cleaning, initial suscepti- } \\
\text { bility of basalts; } \\
\text { ARM acquisition by basalts }\end{array}$ & 7 \\
\hline $\begin{array}{l}\text { Glomar Challenger/ } \\
\text { Dalhousie } \\
\text { University }\end{array}$ & Ade-Hall and Johnson & $\begin{array}{l}\text { NRM of sediments with } \\
\text { AF cleaning }\end{array}$ & 8 \\
\hline $\begin{array}{l}\text { Dalhousie } \\
\text { University/Glomar } \\
\text { Challenger }\end{array}$ & $\begin{array}{l}\text { Ade-Hall, Johnson, } \\
\text { and Ryall }\end{array}$ & $J_{s-t}$ for basalts & 9 \\
\hline $\begin{array}{l}\text { Glomar Challenger/ } \\
\text { Dalhousie } \\
\text { University/ } \\
\text { University of Maine }\end{array}$ & $\begin{array}{l}\text { Ade-Hall, Fink, and } \\
\text { Johnson }\end{array}$ & $\begin{array}{l}\text { Opaque petrography of } \\
\text { basalts; grain size and } \\
\text { abundance of opaque } \\
\text { phases }\end{array}$ & 10 \\
\hline
\end{tabular}


TABLE 3

Mean Cleaned NRM Inclination for Leg 34 Sediment $\left(^{\circ}\right)$

\begin{tabular}{lccc}
\hline & 319 & 320 & 321 \\
\hline $\begin{array}{l}\text { Assuming all samples } \\
\text { have the same } \\
\text { polarity }\end{array}$ & $\begin{array}{l}14 \pm 7^{\circ} \\
\text { (SD of mean) }\end{array}$ & $08 \pm 11^{\circ}$ & $11 \pm 4^{\circ}$ \\
$\begin{array}{l}\text { Assuming sense of the } \\
\text { inclination is a } \\
\text { reliable guide to } \\
\text { polarity }\end{array}$ & $16 \pm 6^{\circ}$ & $31 \pm 6^{\circ}$ & $15 \pm 3^{\circ}$ \\
$\begin{array}{l}\text { Anticipated inclination } \\
\text { for a centered axial } \\
\text { dipole field }\end{array}$ & \pm 25 & \pm 18 & \pm 23 \\
\hline
\end{tabular}

clinations could be obtained for each site (Table 3). Only for the Site 320 data is there a significant difference between the two mean inclinations obtained in this way.

Measurements of the basalt NRM intensity and demagnetization characteristics are given in Papers 1, 2, 3, 4,5 , and 7 . Alternating field (AF) demagnetization, to obtain remanence characteristics and stable directions, was preferred by most groups to thermal demagnetization. However, Paper 2 describes similar mean stable directions for groups of samples from each site subjected to AF and thermal cleaning, respectively. While fine-grained samples gave little difficulty during AF cleaning, the coarse-grained basalt or dolerite from Site 321 and, particularly, Site 319, gave difficulty to several groups $(3,5)$. In general it seems clear that attention must be given to the design of demagnetizing equipment since it now seems probable that deeper basement penetration will yield appreciable amounts of coarsegrained, magnetically soft material. Success in obtaining stable directions from the coarse-grained basalts was reported in Papers 1 and 7, where demagnetization procedure allowed for or prevented the acquisition of rotational remanent magnetization (Wilson and Lomax, 1972).

Undemagnetized NRM values (Table 4) were lower than reported for pillow basalts dredged from ridge crest areas (Irving et al., 1970), but are comparable with values from other DSDP sites (Lowrie et al., 1973; Lowrie, 1974).

An apparently very significant feature of the undemagnetized NRM intensities, $J_{o}$, is the two orders of magnitude range in values. The most strongly magnetized material is fresh, coarse-grained massive basalt, while altered massive basalt and pillow basalt are much weaker (7). Site 319 is represented by both alteration states of basalt, Site 320 exclusively by altered pillow fragments and Site 321 largely by little altered or unaltered massive basalt. This relationship is independent of site age. This distinction is apparent in all collections where the basalts in the two states of alteration can be identified, and accounts for at least a major part of the differences in the average $J_{o}$ values obtained by different groups (Table 4). The generally higher average $J_{o}$ values for Site 321 are probably a consequence of the $\mathrm{FeTi}$ (high iron and titanium content) chemistry of the basalt at this site (Kempe, this volume). The high average titanomagnetite contents for basalts from Site
321 (Paper 9) must be a result of this enrichment in iron and titanium. There are two ways to obtain the average $J_{o}$ values for the basement sections at each site; one is to average the values from different samples and the other is to weight the average to allow for the fact that massive basalts were recovered during drilling much more successfully than were pillow and other fine-grained basalts. The two averages depart significantly only at Site 319 , where a weighted $J_{o}$ value $27 \%$ less than the unweighted value was obtained (7). Clearly $J_{o}$ for layer 2 at each site will depend critically on the overall ratio of the two types of basalt in the section.

Induced magnetization is generally higher than is found for ridge crest dredgehaul basalts and again clearly relates to the division between fresh, coarse-grained and altered coarse and fine-grained basalts, with higher values for the former. The overall average $Q$ ratios for the three sites assuming an in situ field of 0.3 oe, range from 7 to 33 (Table 4). Since induced magnetization is highest in the fresh massive basalts, where it approaches $J_{o}$ in magnitude, its importance in layer 2 as a whole will again depend on the ratio of the two types of basalt in a particular section. Paper 2 shows that initial susceptibility (and thus induced magnetization) varies markedly with temperature with peaks in the $0^{\circ}-100^{\circ} \mathrm{C}$ range for the little altered massive basalts. This result may have implications for the contribution to anomaly patterns of deeply buried basement rocks.

Assessment of the in situ viscous magnetization (VRM) of the basalts is difficult, in view of the uncertainty regarding the part of $J_{o}$ of viscous origin and of the major temporal extrapolations required if laboratory data are to be used to predict moments acquired during the $7 \times 10^{5} \mathrm{yr}$ interval since the last worldwide geomagnetic reversal. A satisfying feature of the VRM studies of Papers 3, 4, and 5 is the agreement on a common experimental approach. In each case, laboratory VRMs were acquired over the same time interval of 500 $\mathrm{hr}$, making the comparison of results easier. In Table 4 we have reduced the results of the VRM measurements of 3,4 , and 5 to a common datum, the time in years for a VRM to be acquired equal to half the magnitude of $J_{0}$. Above this level, VRM forms the dominant part of the NRM. If this time is less than $7 \times 10^{5} \mathrm{yr}$, and the measured NRM can be shown to be the same as the in situ magnetization, then it is safe to assume that the measured NRM is largely a VRM acquired during the present normal geomagnetic polarity epoch. Before discussing the relative magnitudes of VRM and NRM we must look at an important NRM property: the nature of the soft components identified during AF demagnetization. Soft components for many collections of young subaerial basalts are aligned at close to the ambient geomagnetic field direction and can safely be interpreted as VRMs acquired over the last $7 \times 10^{5} \mathrm{yr}$. However, while large soft or secondary components form part of the VRM of the coarser grained Leg 34 basalts, their inclinations are far from the present or dipole geomagnetic ambient field inclinations. Thus, we have very large secondary components directed nearly vertically upwards for Hole 319A $(1,4,7)$ and moderately steeply downwards at Site 321 (7). At each site the present and axial geo- 
TABLE 4

\begin{tabular}{|c|c|c|c|c|}
\hline Paper & $\begin{array}{l}\text { No. of } \\
\text { Samples }\end{array}$ & $\begin{array}{c}\text { Average NRM } \\
\text { Intensity } J_{o} \\
\times 10^{4} \mathrm{emu} \\
\mathrm{cm}^{-3}\end{array}$ & $\begin{array}{c}\text { Average } \\
Q \text { ratio }=J_{O} / K F \\
(F: 0.3 \mathrm{oe})\end{array}$ & $\begin{array}{c}\text { Time for VRM Acquired } \\
\text { in } 0.3 \text { oe to Equal } \\
\left(J_{o} / 2\right) \\
(\mathrm{yr})\end{array}$ \\
\hline \multicolumn{5}{|c|}{ Holes 319 and 319A } \\
\hline 1 & 14 & $\begin{array}{l}14.1 \pm 2.6(\mathrm{SD} \\
\text { of mean) }\end{array}$ & $6.1 \pm 2.1$ & - \\
\hline 2 & 27 & $10.8^{\mathrm{a}}$ & $3.8^{\mathrm{a}}$ & - \\
\hline 3 & 10 & $5.0 \pm 1.3$ & - & $\begin{array}{l}0.55 \text { to } 3 \times 10^{88}, 4 \text { of } \\
7 \text { samples between } \\
0.55 \text { and } 314, \text { others } \\
>5 \times 10^{11}\end{array}$ \\
\hline 4 & 7 & $17.2 \pm 1.9$ & $\begin{array}{l}3 \text { for } 6 \text { of } \\
7 \text { samples }\end{array}$ & 7 samples 0.03 to 3 \\
\hline 5 & 6 & $12.0 \pm 3.3$ & - & $\begin{array}{l}1 \text { to } 10^{54}, 3 \text { of } 6 \\
\text { samples between } 1 \\
\text { and } 430, \text { others }>10^{34}\end{array}$ \\
\hline 7 & 15 & $\begin{array}{l}23.8 \pm 5.7^{b} \\
(17.4 \pm 5.9)^{b}, c\end{array}$ & $12.2(16.3)^{\mathrm{b}}$ & \\
\hline Averag & values & 13.9 & 7.3 & $\begin{array}{l}14 \text { of } 20 \text { samples } \\
\text { between } 0.03 \text { and } 430 \\
\text { rest }>5 \times 10^{11}\end{array}$ \\
\hline \multicolumn{5}{|c|}{ Site 320} \\
\hline 1 & 2 & $4.9 \pm 0.0$ & $14.7 \pm 1.4$ & - \\
\hline 2 & 2 & $2.2^{\mathrm{a}}$ & $5.1^{\mathrm{a}}$ & - \\
\hline 3 & 1 & 6.2 & - & $\begin{array}{l}\text { One sample, time } \\
\text { indeterminate }\end{array}$ \\
\hline 4 & 0 & - & - & - \\
\hline 5 & 0 & - & - & - \\
\hline 7 & 6 & $\begin{array}{l}13.2 \pm 2.9 \\
(13.2 \pm 7.6)^{\mathrm{c}}\end{array}$ & $39 \pm 7$ & - \\
\hline Averag & values & 10.6 & 33 & - \\
\hline \multicolumn{5}{|c|}{ Site 321} \\
\hline 1 & 8 & $96.6 \pm 13.6$ & $10.1 \pm 2.5$ & - \\
\hline 2 & 17 & $93.4^{\mathrm{a}}$ & $12.9^{\mathrm{a}}$ & - \\
\hline 3 & 1 & 2.1 & - & One sample, $6 \times 10^{62}$ \\
\hline 4 & 4 & $71.0 \pm 12.1$ & 3.9 to 10.8 & $\begin{array}{l}4 \text { Samples between } 156 \\
\text { and } 473,000\end{array}$ \\
\hline 5 & 5 & $120 \pm 9$ & - & $\begin{array}{l}5 \text { samples between } \\
4 \times 10^{24} \text { and } 4 \times 10^{70}\end{array}$ \\
\hline 7 & 13 & $103 \pm 23(96 \pm 23)^{c}$ & $6 \pm 1$ & - \\
\hline \multicolumn{2}{|c|}{ Average values } & 95.5 & 10.0 & $\begin{array}{l}\text { No concensus on VRM } \\
\text { acquisition for Site } 321 \\
\text { samples }\end{array}$ \\
\hline
\end{tabular}

${ }^{\mathrm{a}}$ Geometric average values, otherwise arithmetic averages.

${ }^{b}$ Value for an equivalent single component NRM.

${ }^{c}$ Value in parentheses weighted to account for the differential recovery of pillow basalt and massive basalt.

magnetic fields have shallow upwards inclinations. In Papers 4 and 7 these soft components have been interpreted as being VRMs wholly or partly resulting from strong local magnetic fields associated with the drill string and the mechanical impulses involved in drilling. If this interpretation is correct, then the measured
NRMs do not represent the in situ viscous magnetization. With our limited knowledge of the stress and local magnetic fields associated with drilling activity, it is difficult to relate the magnitude of the observed soft components to the moment acquired in $0.3 \mathrm{oe}$, the ambient field intensity at Sites 319 and 321 . However, 
Paper 4 indicates that exposure to a field as small as 4 oe for an interval of a few hours, which is typical of the time required to core 9.5 meters of basalt, would be sufficient to generate the observed soft components. Nevertheless, even with the uncertainties involved in extrapolating behavior over $500 \mathrm{hr}$ to $7 \times 10^{5} \mathrm{yr}$, and in estimating conditions during drilling, a significant number of fresh massive coarse-grained basalts from Site 319 acquire VRM so readily that it seems certain that their in situ magnetization is dominated by VRM (Table 4). A number of other samples, from all three sites, sometimes identifiable from their stratigraphic level as being fine grained or altered, have negligible ability to acquire VRM.

Estimates of the ability of Site 321 basalts to acquire VRM vary widely, even where it is clear that similar fresh, coarse-grained material has been tested $(4,5)$. The results of Paper 4 indicate that the in situ NRM must be dominated by VRM while the results of Paper 5 imply that stable remanence is dominant. This apparent contradiction encourages us to point out a number of uncertainties in VRM theory and technique, which have probably led to this unsatisfactory situation for the Site 321 basalts. It is the logarithmic nature of the time dependence of the growth of VRM that has amplified the effects of these uncertainties. In the first place, the fit of observations to a logarithmic growth pattern is often uncertain. Frequently points are badly scattered or, when reasonably confined, show two distinct segments. Again, the nature of the dependence of VRM growth on applied field intensity is somewhat uncertain. Even where a linear dependence is assumed, uncertainty in the value of the applied field, as in Paper 5, can have a serious effect in estimating the importance of in situ VRM in an area of clearly different field intensity. Finally, the report that VRM acquisition in undemagnetized samples amounts to twice that in demagnetized samples (4) implies that VRM is likely to be the dominant magnetization in a much larger fraction of the oceanic crust than previously supposed.

The implication that VRM is likely generally to be important in the ocean crust requires that considerable attention be given to the theory and practice of VRM determination, so that reliable quantitative estimates of in situ viscous magnetization in any section can be obtained.

In summary, the net magnetization of layer 2 at each of the three Leg 34 sites will depend on the relative proportions of two types of magnetic material:

1) Fresh massive coarse-grained basalt with high remanent and induced magnetization, with VRM dominating the NRM. Careful attention to demagnetization technique is needed to obtain an original magnetizing field direction from this type of material.

2) Altered massive coarse-grained basalt and finegrained pillow basalt with low remanent and induced magnetization dominated by the NRM. VRM only comprises a small or negligible part of NRM.

With the limited layer 2 penetration at the three Leg 34 sites, it is impossible to estimate the ratio of these two types of magnetic material within the layer as a whole. For this reason the overall magnetic signature of the layer is still unknown.
Details of cleaned remanence directions for the basalts are given in four papers $(1,2,4$, and 7) and are summarized in Table 5. Papers 3 and 5 give some NRM direction information with the proviso that it is difficult to identify stable directions.

It is satisfying that the four groups specifically involved in NRM measurements obtain very similar average basalt cleaned NRM directions for each site, notwithstanding the instability of the fresh massive coarsegrained basalts. The close grouping of directions for each site suggests that the crustal section sampled in each case was formed over a short time interval, probably well within the $10^{3} \mathrm{yr}$ quasiperiodicity of secular variation. Paper 1 suggests that the significantly different cleaned inclinations of altered massive and pillow basalts and the unaltered massive basalts $\left(+51 \pm 1^{\circ}\right.$ against $+67 \pm 4^{\circ}$ ) can be explained by stable CRM acquisition during alteration. This would account for the altered basalts, which were presumably partly remagnetized over a long period of time, during which the average field was close to the dipole inclination, having inclinations between the steep original TRM inclinations and the present dipole inclination. A smaller difference in the same sense is found in the data of Paper 7 $\left(54 \pm 3^{\circ}\right.$ against $60 \pm 1^{\circ}$ ). One basalt from Hole 319A described in Paper 1 has an inclination in the opposite sense from all the others from this site $\left(-71^{\circ}\right.$ compared with +47 to +85 ). This sample has the most cation-deficient titanomagnetite of this set, and it is suggested that it is self-reversed, perhaps by the mechanism proposed by O'Reilly and Banerjee (1967). An alternative explanation for the negative inclination is that it is the result of accidental sample misorientation (1). This explanation is supported by the fact that a soft, drilling induced moment is also reversed with respect to the soft moments of the other coarse-grained basalt samples from Site 319A $(1,6,7)$. Such errors are, unfortunately, not hard to make and the fact that two other probably unaltered samples (319-3-4, 37-40 cm [2], 319A-4-1, 141 $\mathrm{cm}$ [3]) yield unique negative inclinations in their respective sets suggests that sample marking error rather than self-reversal is responsible for the inverted mag-

TABLE 5

Cleaned NRM Inclinations for Leg 34 Basalts

\begin{tabular}{|c|c|c|c|c|}
\hline \multicolumn{4}{|c|}{$\begin{array}{l}\text { Average Cleaned Remanence Inclination } \\
( \pm \mathrm{SD} \text { of the mean })\left({ }^{\circ}\right)\end{array}$} & \multirow{2}{*}{$\begin{array}{c}\text { Anticipated } \\
\text { Inclination } \\
\text { for a } \\
\text { Centered } \\
\text { Axial } \\
\text { Dipole Field }\end{array}$} \\
\hline aper 1 & Paper 2 & Paper 4 & Paper 7 & \\
\hline $3 \pm 3 \mathrm{ad}$ & $+53 a b$ & $+57^{a}$ & $+54 \pm 4^{\mathrm{d}}$ & \pm 25 \\
\hline $0 \pm 3^{a}$ & - & - & $-25 \pm 9 \mathrm{e}$ & \pm 18 \\
\hline $6 \pm 2^{\mathrm{a}}$ & $-15^{a c}$ & $-24 a$ & $-20 \pm 2^{e}$ & \pm 23 \\
\hline
\end{tabular}

${ }^{\mathrm{a}}$ Average obtained giving unit weight to each sample.

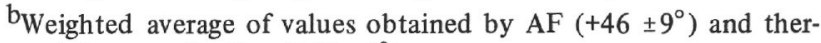
mal demagnetization $\left(+58 \pm 8^{\circ}\right)$.

${ }^{c}$ Weighted average of values obtained by $\mathrm{AF}\left(-17 \pm 5^{\circ}\right)$ and thermal demagnetization $\left(-13 \pm 3^{\circ}\right)$.

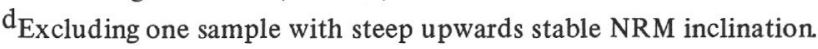

${ }^{\mathrm{e}}$ Average giving unit weight to units rather than samples. 
netization. Inversion, in this case during drilling, is likely to explain the inverted magnetization of one oxidized Site 321 basalt-321-13-4, 91-94 cm (7). It would seem that the evidence for CRM acquisition during low temperature oxidation is more convincing than the evidence for self-reversal.

\section{PRESENT STATE AND ALTERATION HISTORY OF THE MAGNETIC CONSTITUENTS OF THE LEG 34 BASALTS}

Strong field magnetic properties, combined with optical, X-ray, and microprobe tests on the magnetic phases, can be combined to explain the in situ magnetic properties and alteration history of the basalts. At the core of this approach is the fact that the magnetic irontitanium oxides present are extremely susceptible to oxidation, responding rapidly and in different ways to isothermal, hydrothermal, and high temperature (initialcooling) oxidation processes. Papers 1, 2, 9, and 10 are concerned with the effects of oxidation on the magnetic minerals and properties of the basalts.

Determination of the titanium content of the original titanomagnetite of the basalts is the first stage in their investigation as magnetic materials. This has been done by magnetic, chemical, and X-ray means, the presence of unexsolved (class I) titanomagnetite as the dominant oxide phase having first been established from ore microscope observations (10). The variation of saturation magnetization with temperature then provides both initial, stoichiometric, compositions $(x)$, and the degree of nonstoichiometry $(z)$ or cation deficiency, of the titanomagnetite. The latter is important both for what it has to say about the alteration history of the basalt and in providing physical explanations for the observed wide ranges in magnetic properties.

Ozima et al. (1968) show that cation-deficient titanomagnetites do not show reversible behavior during thermal cycling to $600^{\circ} \mathrm{C}$ in a saturating magnetic field, even in vacuum conditions. This criterion is used in 9 to identify samples containing stoichiometric titanomagnetite. Using the relationships between Curie point and $x$ in (1$x) \mathrm{Fe}_{3} \mathrm{O}_{4} x \mathrm{Fe}_{2} \mathrm{TiO}_{4}$ given by Akimoto et al. (1957), Ozima and Larson (1970) and Readman and O'Reilly (1972) the Curie points for stoichiometric titanomagnetite bearing samples have been used to obtain $x$ values. These are listed in Table 6 , together with values obtained by microprobe analysis.

Note that while large Curie point changes occur during oxidation, the small decrease in Fe content and $\mathrm{Fe} / \mathrm{Ti}$ ratio involved in within the repeatability error of microprobe measurements, so that either oxidized or unoxidized samples may be used to obtain $x$ by this method.

Table 6 shows that all statistically well-based values of $x$ are between 0.58 and 0.68 for Site 319 basalts and all very close to 0.63 for Site 321 basalts. A small but significant difference exists between the determinations for $x$ for the Site 319 basalts by the two microprobe groups. The low microprobe analysis for $x$ for a Site 321 basalt reported in 9 is at least partly due to beam spreading into silicate adjacent to the titanomagnetite being analyzed. This is a general experimental difficulty with fine-grained basalts and may also account for the relatively low value for a single Site 320 basalt, for which only pillow fragments were recovered. A further point of interest is the agreement of $x$ values for the Leg 34 basalts with the narrow range in $x$ reported elsewhere for widely distributed collections of subaerial basalts (Creer et al., 1970; Ade-Hall et al., 1971). Finally, we note that both Papers 1 and 9 show that basalts with stoichiometric titanomagnetite, or a minimal degree of cation deficiency in titanomagnetite, are restricted to the coarse-grained massive basalts from Site 321 and to the lower part of the coarse-grained massive basalts from Site 319. The titanomagnetites of all the other basalts are moderately to highly cation deficient.

In order to determine the degree of cation deficiency of a titanomagnetite, it is necessary to know the corresponding value of $x$. Since $x$ is only well known for the Site 319 and 321 basalts, it is only at these sites that, $z$, the degree of cation deficiency, can be obtained. ( $z$ is defined as the fraction of initial $\mathrm{Fe}^{2+}$ oxidized to $\mathrm{Fe}^{3+}$ in the titanomagnetite.) The parameter $z$ can be determined in several ways; in particular from the intersection of oxidation lines and contours of either equal Curie point or of equal unit call size on an iron-titanium oxide ternary diagram. Both methods have been used in Paper 1 (assuming an initial $x$ value of 0.65 ) and the former in Paper 9. It is clear from these reports, and from Curie points listed in 2 and 4, that the basalts fall clearly into two groups; those with stoichiometric (9) or low cation deficiency titanomagnetites (1) and those with highly cation-deficient titanomagnetites $(1,9)$. The difference in opinion on whether the least-oxidized titanomagnetites are stoichiometric (9) or slightly to moderately cation deficient (1) largely arises from different approaches to the interpretation of similar data. The general agreement on the higher $z$ values is a consequence of the small change in $z$ with Curie point and unit cell size for high $z$. We note that $z$ for titanomagnetites (more properly titanomaghemites) in pillow fragments and altered coarse-grained massive basalts is typically in the range $0.6 \leq z \leq 0.9$ with a peak value of 0.96 .

The identification of these highly cation-deficient titanomagnetites has a number of important implications for both the alteration history and the magnetic character of the basalts. Highly cation-deficient phases are notoriously unstable at even moderately elevated temperatures as a result of the very low activation energy of phase splitting (4, Ozima and Ozima, 1972). From laboratory investigations it is known that a titanomaghemite with $z \cong 0.55$ or 0.6 can only be stable at lower than $135-150^{\circ} \mathrm{C}$ (Johnson and Merrill, 1973; Ryall and Ade-Hall, in press). The isotopic composition of secondary calcite at Site 321 indicates that it was formed at $7^{\circ} \mathrm{C}$ while the absence of anhydrite as a secondary mineral in the Site 321 basalts requires that maximum temperature during alteration was less than $60^{\circ} \mathrm{C}$ (Seyfried et al., this volume). It seems very reasonable to associate the formation of the cation-deficient magnetic phases with the low temperature alteration process, known as halmyrolysis, in which seawater reacts with the solid basalt at temperatures of up to at the most a few tens of degrees. We see no sign of the past existence of hydrothermal conditions at any Leg 34 site, 
TABLE 6

Titanomagnetite Composition, $x$ in $(1-x) \mathrm{Fe}_{3} \mathrm{O}_{4} \times \mathrm{Fe}_{2} \mathrm{TiO}_{4}$, of

Leg 34 Basalts (Distributions are RMS About Mean Values)

\begin{tabular}{|c|c|c|c|}
\hline Paper & Site 319 & Site 320 & Site 321 \\
\hline 9 & $\begin{array}{l}0.61^{+0.01^{\mathrm{a}}}-0.03^{-} \\
(n=5)\end{array}$ & $\begin{array}{l}\text { No sample with } \\
\text { stoichiometric } \\
\text { titanomagnetite. }\end{array}$ & $\begin{array}{l}0.63 \pm 0.00^{\mathrm{a}}(n=3) \\
0.51^{\mathrm{b}}(n=1)\end{array}$ \\
\hline $\begin{array}{l}\text { Bunche and } \\
\text { Lalonde } \\
\text { (this volume) }\end{array}$ & $\begin{array}{l}0.58 \pm 0.01^{\mathrm{b}} \\
(n=8)\end{array}$ & - & - \\
\hline $\begin{array}{l}\text { Mazzullo } \\
\text { et al. } \\
\text { (this volume) }\end{array}$ & $\begin{array}{l}0.68 \pm 0.02^{\mathrm{b}} \\
(n=4)\end{array}$ & $\begin{array}{l}0.52^{b} \\
(n=1)\end{array}$ & $\begin{array}{l}0.63 \pm 0.01^{\mathrm{b}} \\
(n=4)\end{array}$ \\
\hline
\end{tabular}

aFrom the variation of saturation magnetization with temperature.

${ }^{b}$ Electron probe microanalyzer result.

notwithstanding the currently popular suggestion that convection in hydrothermal systems is a major source of heat loss in newly formed ocean crust.

Several reports note the marked relationship between variation in magnetic properties and degree of titanomagnetite cation deficiency $(1,9)$. Paper 2 , on the other hand, correlates the variation in magnetic properties with a different physical phenomenon, the presence or absence of significant numbers of oxide grains in the superparamagnetic grain size range.

The problem in explaining the wide range in magnetic properties of the Leg 34 basalts-natural remanent magnetization intensity $\left(J_{o}\right)$, mean demagnetizing field (MDF), initial susceptibility $(k)$, and saturation magnetization $\left(J_{\mathrm{s}}\right)$-is one of the separation of variables, with titanomagnetite abundance, grain size, and degree of deficiency likely to share control of magnetic properties. The problem is illustrated by the fact that while the pillow fragments have low $J_{o}, k$, and $J_{s}$, and high MDF, in complete contrast to the unaltered massive coarsegrained basalts, titanomagnetite content, grain size, and $z$ value generally all differ between the two groups. Two methods have been used to separate the effects of these variables on magnetic properties. Paper 2, using the low field hysteresis properties of the basalts, suggests that grain size provides the fundamental control on magnetic properties. Low Curie point samples (high $J_{o}, k, J_{s}$, low MDF) exhibit loops which are attributed by Radhakrishnamurty and Likhite (1970) to the presence of very fine superparamagnetic particles. High Curie point samples (low $J_{o}, k, J_{s}$, high MDF) do not exhibit Rayleigh loops. However, this interpretation apparently is at variance with microscope observations, which show that low Curie point samples have relatively large (15$30 \mu$ mean particle size with occasional grains larger than $100 \mu$ ) homogeneous titanomagnetite grains, while it is the pillow basalt and other altered samples which, by grain subdivision due to cracks formed during alteration, or by quenching during initial cooling, have the smallest effective grain sizes (10).

Paper 9 assumes no theoretical relationships between oxide and magnetic parameters and instead uses a set of coarse-grained massive basalt samples from Hole 319A to identify the dominant influence on magnetic proper- ties. Here titanomagnetite content and grain size are essentially invariant, leaving a large range in $z$ as the only variable. For this set of basalts every magnetic property clearly varies strongly with $z$; as $z$ increases $J_{o}, k$, and $J_{S}$ decrease and MDF increases. It is suggested that low temperature oxidation, which leads to an increase in $z$ (and the observed correlations) is capable of providing a number of physical changes in the magnetic oxides that will cause large changes in magnetic properties. Not only will $J_{s}$ decrease with increasing $z$, especially for $z$ $>0.6$, but grain subdivision by volume change cracks (10) reduces effective grain size to well below the overall grain size, and replacement of oxide by silicate (10) reduces significantly the amount of oxide present. The possibility exists that the magnetic properties are associated with submicroscopic superparamagnetic or singledomain titanomagnetites (2). However, it seems unnecessary to postulate the presence of an important but invisible magnetic fraction when the properties of the observable titanomagnetites correlate convincingly with magnetic properties (9).

\section{IMPLICATIONS OF MAGNETIC RESULTS FOR THE VOLCANIC GEOLOGY AT THE DRILL SITES}

Paper 6 deals with the important question of whether the volcanic units sampled at Sites 319 and 321 are intrusives or extrusives. This question is usually difficult to answer at DSDP sites, since chilled margins, baked sediments, and other diagnostic lithologies are rarely recovered. The approach of Paper 6 is to look for preferred directions of susceptibility anisotropy in the basalts. A marked preference of the axis of minimum susceptibility to be associated with the horizontal plane for some parts of the Site 319 and all of the Site 321 basalt sections is interpreted as being evidence of intrusive origin. The criterion used for the identification of intrusive units is the observation that, for a wide range of basalts of known emplacement mode, there is an $80 \%$ probability that a magnetic susceptibility anisotropy parameter, $F$, will exceed 1.040 in value in the intrusive mode (Ellwood, in press). Other evidence bearing on this problem is limited. All the Site 319 basalts have closely grouped stable magnetization at steeply down- 
wards inclined anomalous inclination. If this anomalous inclination represents an excursion of the geomagnetic field, then it would seem unlikely that the excursion would persist sufficiently long for both flows and intrusives to acquire the same direction of magnetization. An intrusive origin for the Site 321 basalts would be supported if the age of the basalt was significantly younger than the closely agreeing paleontological, magnetic, and Sclater-Francheteau ages of 38-40 m.y. for the Site. Seidemann (this volume) using the whole rock $\mathrm{K} / \mathrm{Ar}$ technique, finds a maximum age of $28 \pm 3 \mathrm{~m}$.y. for Site 321 basalts, but doubts the validity of the age. Reynolds (this volume), using the $\mathrm{A}^{40} / \mathrm{A}^{39}$ incremental heating technique, gives a best defined age of $37 \pm 1 \mathrm{~m} . \mathrm{y}$. for the Site 321 basalts, but has difficulty in explaining the observed gas release pattern. Again Mitchell and Aumento (this volume) give fission track ages for glass cuttings from Hole 319A that, at $17.8 \pm 3.0$ m.y. agrees with the estimate of basement age based on the fossil content of the overlying sediments. While these absolute ages suggest that the ages of at least some of basement units sampled are close to the predicted ages, the stated errors are large enough to allow for intrusive activity within a few million years of the formation of new crust, perhaps consisting at the upper levels entirely of pillow lavas.

\section{MOTION OF THE NAZCA PLATE OVER THE LAST 40 M.Y.}

One of the aims of paleomagnetic studies of oceanic basement is to give measures of the absolute látitudinal motion of crustal plates. In principle, the mean cleaned NRM inclinations of Tables 3 and 5 may be used for this purpose. We note, however, that the inclination for the Site 319 basalts departs more markedly from the anticipated value than does any other basalt or sediment value. Several papers $(1,7)$ interpret the Site 319 basalt inclination in terms of atypical geomagnetic field conditions or tectonic rotation. The internal consistency of the basalt paleomagnetic inclinations at each site suggest that only short time intervals, of perhaps $1000 \mathrm{yr}$ or less, are represented by the sections penetrated. For this reason the basal sediment sections, where one measurement sample represents an average field inclination for 600-900 yr, are likely to give statistically better based estimates of plate motion than the basalt sections. Analysis of the sediment data of Paper 8 suggests that the maximum latitudinal motion of the Nazca plate over the last 40 m.y. is only $+3 \pm 2^{\circ}$ (standard deviation of the mean), suggesting at the most, a modest southwards motion. This result in consistent with the present absolute motion of the plate, which is apparently almost exactly eastwards (Morgan, 1972).

\section{SUMMARY}

The planned study by eight groups of the magnetic properties of the sediments and basalts recovered in DSDP has been very successful, with a full coverage and a sensible degree of duplication of the range of useful magnetic measurements. Generally, where more than one group has made a particular measurement, the results have agreed closely. Interpretations, on the other hand, are different in some cases.
Several previously unreported ocean crust features have been identified by this cooperative study. In particular:

1) At two of the three Leg 34 sites the magnetic structure of basement sections consist of a combination of two distinctly different types of materials: (a) Coarsegrained massive basalt containing fairly large (15-30 $\mu)$ titanomagnetite grains in a stoichiometric or little oxidized state. Strong remanence, averaging up to $0.01 \mathrm{G}$, strong induced magnetization, approaching the intensity of the remanence, and ability to acquire large viscous acquisition over $500 \mathrm{hr}$ characterize this type of material. Comparison of the different sources of magnetization suggest that the in situ magnetization of this type of material will be dominantly viscous, having the direction of the ambient field. (b) Fine-grained pillow basalt or coarse-grained massive basalt containing highly cation-deficient titanomagnetite. Weak remanence of 0.001 to $0.002 \mathrm{G}$, distinctly weaker induced magnetization, and poor ability to acquire viscous magnetization characterize this type of material. The in situ magnetization will be dominated by the remanent magnetization which will have either the direction of the initial magnetizing field or a combination of this and subsequent field directions resulting from partial chemical remagnetization.

The net magnetization of a basement section composed of these two types of material will depend on their relative proportions in the section. Clearly a large amount of the fine-grained or altered material will be needed to compensate for any of the fresh coarsegrained material present.

2) At all three Leg 34 sites the major control on magnetic properties is the degree of low temperature oxidation of titanomagnetite. With rare exceptions the titanomagnetite of the basalts has avoided the high temperature type of oxidation that is a widespread feature of subaerial basalts. The easily oxidized, homogeneous titanomagnetite has reacted with seawater at no more than a few tens of degrees centigrade giving rise to highly altered zones interleaved with little altered zones. The degree of titanomagnetite cation deficiency resulting from this chemical interaction correlates strongly with magnetic properties, with NRM intensity, initial susceptibility, and saturation magnetization decreasing and mean demagnetizing field increasing with increasing cation deficiency. Aside from cation deficiency, reduced titanomagnetite effective grain size and abundance also result from the low temperature oxidation process.

Other features of interest are evidence for negligible latitudinal motion of the Nazca plate over the last 40 m.y., the identification of strong viscous magnetization induced during the drilling process, and an attempt, through susceptibility anisotropy measurements, to determine the intrusive or extrusive nature of the coarsegrained massive basalt of Sites 319 and 321.

\section{ACKNOWLEDGMENTS}

We would like to acknowledge the willing assistance of all the groups involved in this cooperative magnetic study of material recovered on DSDP Leg 34. I would also like to thank my wife Lata and daughter Mair for their continued patience while this chapter, my seventh contribution to the Leg 
34 Initial Report, has been slowly put together. Monika Michaelis has, as always, made an excellent job of interpreting my execrable handwriting in order to type this report. Patrick Ryall was kind enough to act, yet again, as critical reader.

\section{REFERENCES}

Ade-Hall, J.M., Palmer, H.C., and Hubbard, T.P., 1971. The magnetic and opaque petrological response of basalts to regional hydrothermal alteration: Geophys. J., v. 24, p. 137-174.

Akimoto, S., Katsura, T., and Yoshida, M., 1957. Magnetic properties of the $\mathrm{TiFe}_{2} \mathrm{O}_{4}-\mathrm{Fe}_{3} \mathrm{O}_{4}$ system and their change with oxidation: J. Geomag. Geoelect., v. 9, p. 165.

Anderson, R.N., and Sclater, J.G., 1972. Topography and evolution of the East Pacific Rise between $5^{\circ} \mathrm{S}$ and $20^{\circ}$ S: Earth Planet. Sci. Lett., v. 14, p. 433-441.

Creer, K.M. and Ibbetson, J.D., 1970. Electron microprobe analyses and magnetic properties of non-stoichiometric titanomagnetites in basaltic rocks: Geophys. J., v. 21, 485511.

Ellwood, B.B., in press. Analysis of emplacement mode in basalt from DSDP Holes 319A and 321 using anisotropy of magnetic susceptibility: J. Geophys. Res.

Herron, E.M., 1972. Sea floor spreading and the Cenozoic history of the east-central Pacific: Geol. Soc. Am. Bull., v. 83, p. 1671-1692.

Irving, E., Park, J.K., Haggerty, S.E., Aumento, F., and Loncarevic, B., 1970. Magnetism and opaque mineralogy of basalts from the Mid-Atlantic Ridge at $45^{\circ} \mathrm{N}$ : Nature, v. 228 , p. $974-976$.

Johnson, H.P. and Merrill, R.T., 1973. Low temperature oxidation of a titanomagnetite and the implications for paleomagnetism: J. Geophys. Res., v. 78, p. 4938-4949.
Lowrie, W., 1974. Oceanic basalt magnetic properties and the Vine and Matthews hypothesis. J. Geophys./Z fur Geophys., v. 40, p. 513-536.

Lowrie, W., Lovlie, R and Opdyke, N.D., 1973. Magnetic properties of Deep Sea Drilling Project basalts from the North Pacific Ocean: J. Geophys. Res., v. 78, p. 7647-7660.

Morgan, W.J., 1972. Plate motions and deep mantle convection: Geol. Soc. Am. Mem. 132, p. 7-27.

O'Reilly, W. and Banerjee, S.K., 1967. Mechanism of oxidation in titanomagnetites, a magnetic study: Mineral Mag., v. 36, p. 29-37.

Ozima, M. and Larson, E. E., 1970. Low and high temperature oxidation of titanomagnetite in relation to irreversible changes in the magnetic properties of submarine basalts: J. Geophys. Res., v. 75, p. 1003-1018.

Ozima, M. and Ozima, M., 1972. Activation energy of the unmixing of titanomaghemite. Phys. Earth. Planet. Int., v. 5, p. $87-89$.

Ozima, M., Ozima, M. and Kaneoka, I., 1968. Potassium argon ages and the magnetic properties of some dredged submarine basalts and their geophysical significance: J. Geophys. Res., v. 73, p. 711-723.

Radhakrishnamurty, C. and Likhite, S.D., 1970. Relation between thermal variation of low field susceptibility and magnetic hysteresis in basalts: Earth Planet. Sci. Lett., v. 9, p. 294-298.

Readman, P.W. and O'Reilly, W., 1972. Magnetic properties of oxidized (cation deficient) titanomagnetites (Fe, Ti, $\square)_{3} \mathrm{O}_{4}$ : J. Geomag. Geoelect., v. 24, p. 69-90.

Ryall, P.J.C. and Ade-Hall, J.M., in press. Radial variation of magnetic properties in submarine basalt pillows: Canadian J. Earth Sci.

Wilson, R.L. and Lomax, R., 1972. Magnetic remanence related to slow rotation of ferromagnetic material in alternating magnetic fields: Geophys. J., v. 30, p. 295-304. 